\title{
Plaster Models and Plaster Casts of Classical Architecture and its Decoration
}

\author{
VALENTIN KOCKEL
}

Standards for drawing and reproducing ancient architecture had emerged towards the end of the seventeenth century. These standards rested on the techniques of contemporary architects and focused on scale and proportions. ${ }^{1}$ The great 1682 publication by Antoine Desgodetz, which had been financed by the Paris Academy, became and remained for decades the ideal model for every sophisticated work on ancient architecture. ${ }^{2}$ The buildings, in their groundplan, elevation, and sections, were represented in orthogonal projection, so that one could easily read off the proportioning of the component parts to one another (Fig. 23. 1). The same method was used for representations of capitals and entablatures, and we can even verify that the individual details were uniformly distributed on the pages of books by different authors. Here, too, the authors followed Vitruvius in emphasizing the proportioning of the single elements to one another. Antoine Desgodetz and later Giambattista Piranesi usually give 'moduli' instead of absolute measurements.

Apart from two-dimensional drawings there were two main options for three-dimensional reproductions of ancient architecture: downsizing to a handy model and casting single elements in a mould in their original size. While a satisfactory model could be constructed with the help of published drawings or with corrected versions of these drawings or engravings, the cast required a special logistical effort. Unlike three-dimensional reproductions of coins, gems, or sculptures, architectural casts posed not only bureaucratic difficulties but also a number of technical challenges that made them also rather expensive. For one thing, the buildings could not be cast full-size in their entirety. Even single decorations are difficult to reach, and a complicated technical

1 V. Kockel, 'Ichnographia - Orthographia - Scaenographia. Abbildungsmodi antiker Architektur am Beispiel des Columbarium der Liberti der Livia', in V. Kockel and B. Sölch (eds), Francesco Bianchini (1662-1729) und die europäische gelehrte Welt um 1700 (Berlin, 2005), pp. 107-133.

2 A. Desgodetz, Les édifices antiques de Rome, mesurés et dessinés très exactement (Paris, 1682, new editions also in English in the 1770s). 

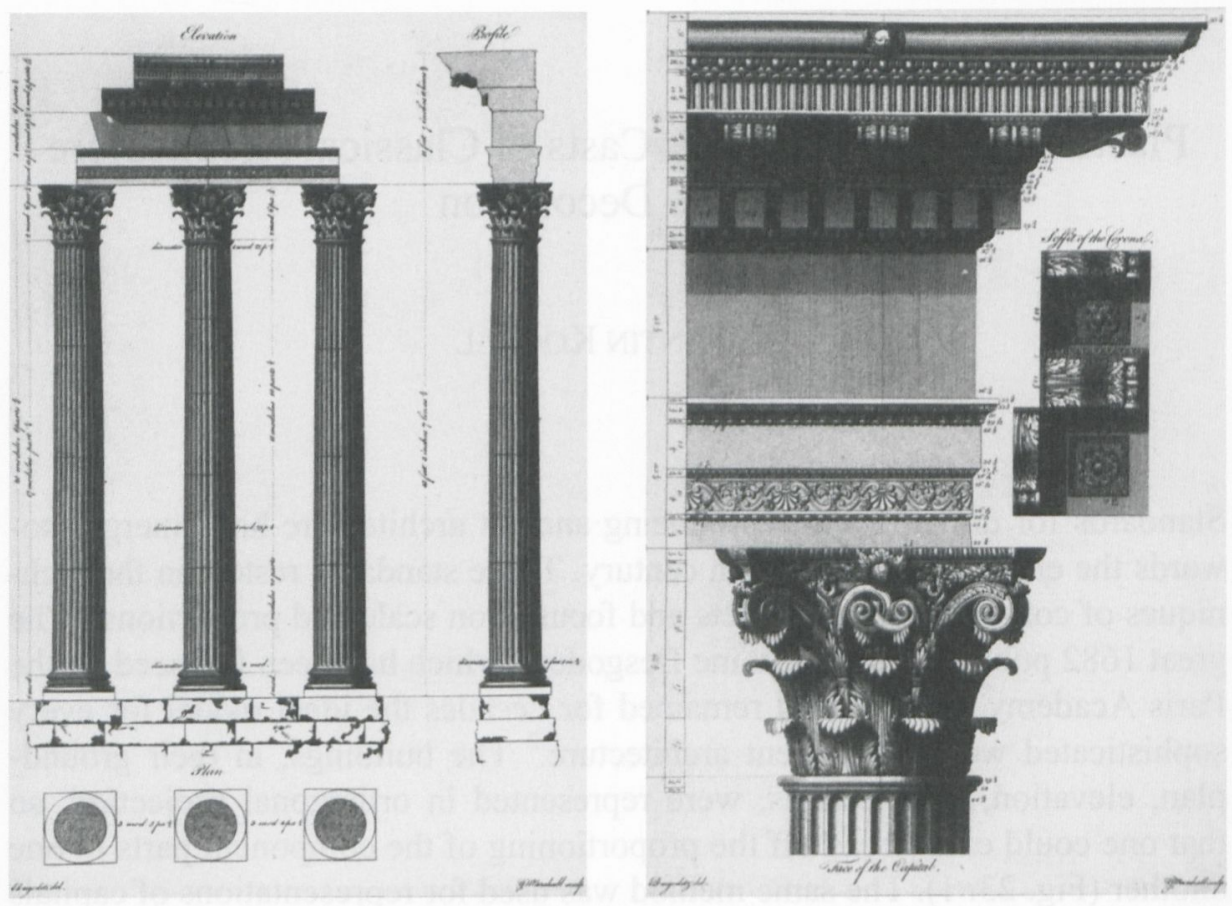

Fig. 23. 1: Of the three columns in the Campo Vaccino at Rome. Engraving in A. Desgodetz, Les édifices antiques de Rome (Paris 1682, engl. edn, London, 1771), I, pls 1-2.

procedure such as casting requires elaborate logistics. Despite all this, in the late eighteenth and early nineteenth centuries, collections were created not only of architectural models but, in several cases, of casts of architectural elements or details. It was only from the mid nineteenth century onwards that it became possible to reproduce entire sections of temples and to confront the observer with the physical monumentality of ancient architecture in the museum.

Today, these collections of reproductions of ancient architecture are often dispersed, inaccessible to the public, or even destroyed. The history of each one of them is complicated and can only be reconstructed through extensive archival research. This has been done for the collection of the Académie des Beaux-Arts (by Werner Szambien ${ }^{3}$ and Christiane Pinatel ${ }^{4}$ ) and, quite recently,

3 Szambien, Le musée d'architecture.

4 Pinatel, 'Les envois de moulages d'antiques', in Lavagne and Queyrel (eds), Les moulages de sculptures antiques, pp. 75-120; Pinatel, 'La restauration en plâtre de deux colonnes'; I. Kader and C. Schreiter, 'Eine vergessene Attraktion. Das Museum für Gipsabgüsse in Versailles', Antike Welt, 30 (1999), pp. 245-52. 
for the Royal Architectural Museum (by Edward Bottoms ${ }^{5}$ ). Contributions on the collections of John Soane ${ }^{6}$ and of the South Kensington Museum (now the Victoria and Albert Museum) can be found in the present volume. In the following, I will confine myself to a 'tour d'horizon'; I will try to emphasize some categories and focal points that seem to me important. I will begin with the models and then proceed to the full-size casts.

\section{Models in Cork and Plaster}

In the $1760 \mathrm{~s}$, the first attempts had been made in Rome to construct models in wood and cork of the most important ancient ruins. The English painter and art dealer Thomas Jenkins was one of the first to have the round temple at Tivoli modelled by the Neapolitan craftsman Giovanni Altieri; he presented it to the London Society of Antiquaries (Fig. 23. 2). ${ }^{7}$ At the same time, Charles Townley commissioned models of the temples of Paestum. ${ }^{8}$ Cork was regarded at the time as a congenial material to reproduce the porous stone of Paestum and Tivoli. Later, it was also used for Roman marble buildings and even for the Stonehenge ruins. ${ }^{9}$

5 E. Bottoms, 'The Royal Architectural Museum in the light of new documentary evidence', Journal of the History of Collections, 19 (2007), pp. 115-39.

6 First notes in Dorey, 'Soane as a collector', in Thornton and Dorey (eds), A Miscellany of Objects, p. 124.

7 On the history of cork models see A. Büttner, 'Korkmodelle', in P. Gercke (ed.), Antike Bauten in Modell und Zeichnung um 1800 (Kassel, 1986), pp. 10-19; V. Kockel, 'Rom über die Alpen tragen. Korkmodelle antiker Architektur im 18. und 19. Jahrhundert', in W. Helmberger and V. Kockel (eds), Rom über die Alpen tragen. Fürsten sammeln antike Architektur: Die Aschaffenburger Korkmodelle (Landshut, 1993), pp. 11-13; V. Kockel, Ruins in Miniature. Cork models of Ancient Monuments in Sir John Soane's Museum and in other English Collections (London, forthcoming); E. Bottoms, 'The Royal Architectural Museum in the light of new documentary evidence', Journal of the History of Collections, 19 (2007), pp. 115-39, at p. 131, fig. 10, gives a photo of this earliest model. It has since been lost.

8 We learn this from eight so far unpublished letters of the architect Vincenzo Brenna to Townley from 1768/69. These letters were first referred to by I. Jenkins, in A. Wilton and I. Bignamini (eds), Grand Tour: The Lure of Italy in the Eighteenth-Century, exh. cat. London and Rome (London, 1996; Milan, 1997), p. 244 no. 185. See also G. Vaughan, 'Vincenzo Brenna romanus: architectus et pictor', Apollo, 144 (1996), pp. 37-41. J. Wilton Ely, Piranesi, Paestum \& Soane (London, 2002), p. 18, probably also used this source. I am particularily indebted to Letizia Tedeschi, Mendrisio, who kindly gave me access to a transcript of the letters she is going to publish.

9 There are models of Stonehenge in the Soane's Museum and the Devizes Museum. On the complicated history of these and other models see my forthcoming Ruins in miniature. See also Thornton and Dorey, A Miscellany of Objects, p. 68 fig. 66; C. Chippindale, Stonehenge complete 2nd edn (London, 1994), p. 81 fig. 56; C. Evans, 'Megalithic Follies', Journal of Material Culture, 5.3 (2000), p. 356 fig. 6. 


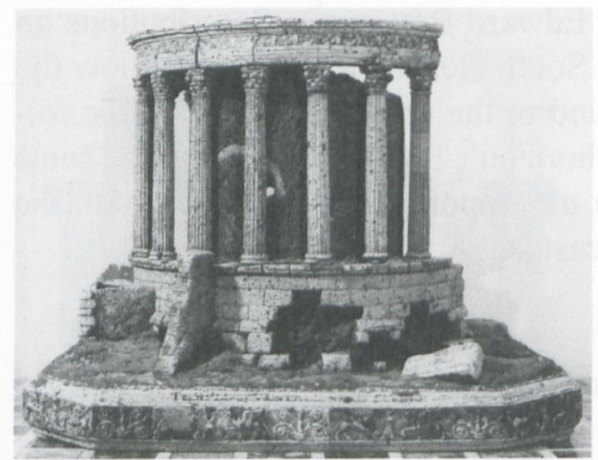

Fig. 23. 2: Model of the temple at Tivoli. G. Altieri, 1770s. Cork and wood, h: $41 \mathrm{~cm}$. Sir John Soane's Museum, London.
From the beginning, the models were expected to be highly precise. ${ }^{10} \mathrm{We}$ often find claims to exactness and information on their scale. Even though these claims fall short of present-day standards, at the time these would have been seen as substantially exact reproductions of the ruins. However, there was considerable doubt as to whether a model could adequately transfer the real and ideal grandeur of antiquity. ${ }^{11}$ The principle underlying every model - reducing reality to a manageable size and thus rendering it accessible for everyone - was in

conflict with the reverence felt in front of an ancient temple.

Cork models always show the remnants of ancient buildings in their current ruinous condition, but mostly without the additions and changes made since antiquity. For the buildings of Rome and its immediate environs a kind of canon evolved, a canon of thirty-six models covering all the various functions and forms of Roman architecture and following the repertoire of guide books and vedutists. The temples of Paestum were also included since they were, at first, the only Doric buildings that were easily accessible. However, there are also single models that were constructed on commission to document, for example, Vesuvius, the excavations of Pompeii (Fig. 23. 3) ${ }^{12}$, in the Colosseum ${ }^{13}$ or on the Forum Romanum. ${ }^{14}$

10 "The admirer of architecture sees here preserved to the most critical nicery all those beautiful proportions [...] Mr. Dubourg has contrived to give every natural tint incident to the materials of the buildings [...]" exclaimed a short newspaper article extolling the virtues of 'Mr. Du Bourg's exhibition of large models cut in cork' in London in 1785. For Dubourg's show see R. Altick, The shows of London (London, 1978), pp. 115-116, 392-3. See also my forthcoming Ruins in miniature.

11 "I have a doubt myself whether these great Columns will not lose their effect in miniature, tho the Proportions may be very exact, yet the Magnificence of the Building will not be seen in the Model", the English traveller Charles Parker wrote to his cousin, Sir Roger Newdigate, in 1783 about Rosa's model of the Temple of Neptune in Paestum. M. McCarthy, 'Documents on the Greek Revival in Architecture', Burlington Magazine, 114 (1972), pp. 760-9.

12 Valentin Kockel, Phelloplastica (Stockholm, 1998), pp. 72-89.

13 See the different models of Carlo Lucangeli, today in Rome (Colosseum) and Paris (Académie des Beaux-Arts), C. Lucangeli, Il colosseo di Roma, della grandezza di palmi 2449 di circonferenza ... (Rome, 1813); G. Schingo, 'I modelli del Colosseo', in A. La Regina (ed.), Sangue e Arena (Rome, 2001), pp. 105-15. 


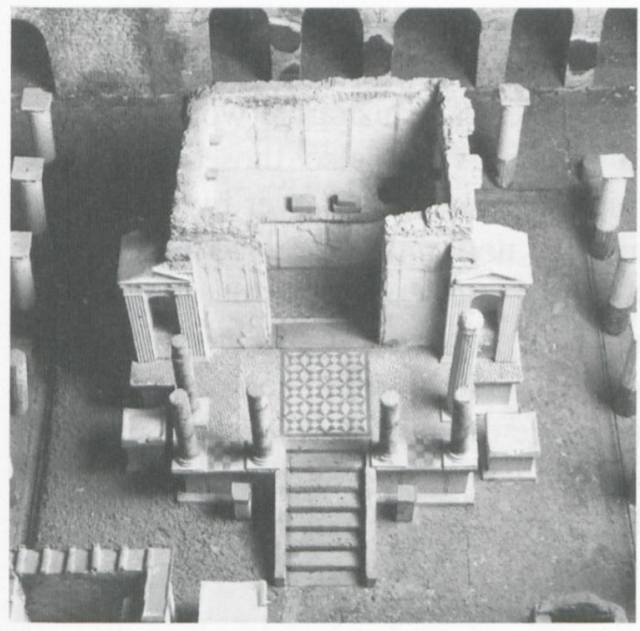

Fig. 23. 3: Model of the temple of Isis in Pompeii. G. Altieri, 1784. Cork and wood, 1: $2.22 \mathrm{~m}$, w: 1.72 m. Royal Castle, Drottningholm.

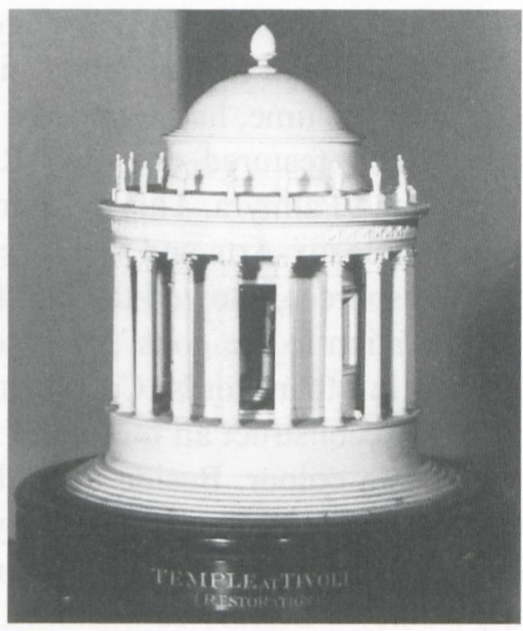

Fig. 23. 4: Model of the temple at Tivoli, restoration. François (?) Fouquet, c. 1830. Plaster, h: $20 \mathrm{~cm}$. Sir John Soane's Museum, London.

Cork models were not made from the bark of the cork oak alone. The ornamental details of ancient architecture in particular turned out to be too minute to be reproduced in this material. Therefore, steel moulds were constructed for capitals, friezes, and figural reliefs. These elements were first formed with plaster in the moulds and then inserted into the cork models.

In the 1780 s, completely white models of ancient architecture emerged alongside the colourful, picturesque cork models. These white models were made of a fine plaster, the 'Plaster of Paris'. As far as we know today, almost all of them come from two modellists, Jean-Pierre Fouquet and his son François, both working in Paris (Fig. 23. 4). ${ }^{15}$ Jean-Pierre worked for the architect and antiquarian Charles-Louis Clérisseau and, later, for the wealthy collector and French ambassador to the Turkish court, the Comte Choiseul-Gouffier. His most effective contribution, however, was probably the numerous models

14 V. Kockel, 'Towns and Tombs: Three-Dimensional Documentation of Archaeological Sites in the Kingdom of Naples in the Late Eighteenth and Early Ninteenth Centuries', in I. Bignamini (ed.), Archives \& Excavations (London, 2004), pp. 143-62. John Soane Jr. mentions in 1819 a "model of the different levels in the Forum", that had been built for John Sanders. We do not know the material of this (lost) model, A. T. Bolton, The Portrait of Sir John Soane ... Set Forth in Letters From His Friends (London, 1927), p. 281.

15 G. Cuisset, 'Jean-Pierre et François Fouquet, artistes modeleurs', Gazette des beaux-arts, 6 ser. 115 (1990), pp. 227-40. 
exhibited in the Musée d'Architecture of François-Louis Cassas from 1806 on. Cassas, who had travelled in Italy, Greece, and the Orient himself for a considerable time, had founded a sort of museum of historical world architecture which featured not only Roman buildings but also those of Greece, Egypt, and Palmyra. This museum, which was later taken over by the Académie des Beaux-Arts and whose contents can now only be reconstructed from written sources, showed the buildings as they had looked "on the day of their consecration to the gods", as a contemporary description puts it rather poetically. ${ }^{16}$ In other words, Cassas and Fouquet had consulted scholarly publications to reconstruct all buildings, which made the radiant white appear appropriate as a colour. Beside the collections of Choiseul-Gouffier and Cassas, a number of models found their way to England: they were owned by John Nash - whose enthusiasm for 'plaister' is well-known - by John Soane, ${ }^{17}$ and by the Bodleian Library of Oxford.

Cork and plaster models thus allowed for two kinds of perspective on antiquity. While the porous material emphasized the picturesque character and transience of the buildings, the white, smooth plaster models reflected a classical idea that could be reconstructed through scholarly study and presented as exemplary for the present day. In the collections of Cassas, Choiseul-Gouffier, and Soane one could see both types of models side by side. In addition, Cassas and Soane exhibited drawn or painted views, illustrating the scenic context of the buildings. This made it possible for the visitor to compare the topography, condition, and original idea of the building in the museum, studying them to a better effect than at the actual site. Even the illumination of the models could be varied, and painters could study the ruins in their studios in London or Paris as elements of ideal landscape. ${ }^{18}$

The general rule - cork for ruins, plaster for reconstructions - was, I think, maintained up to the mid nineteenth century, with only one exception: the models of Athenian buildings that the French painter, traveller, collector, and consul Louis-François-Sébastien Fauvel constructed (or had constructed). For

16 For the methods and plausibility of these reconstructions: J. G. Legrand, Collection des chefs d'oeuvre de l'architecture des différents peuples, exécutés en modèles, sous la direction de L.F. Cassas (Paris, 1806), pp. xix-xxii.

17 Soane bought these models in 1834 from Edward Cresy, who had lived in Paris. See Dorey, 'Soane as a collector', in Thornton and Dorey (eds), A Miscellany of Objects, p. 118, fig. 123.

18 This argument is found repeatedly in descriptions of the time. cf. J. G. Legrand, Collection des chefs d'oeuvre de l'architecture des différents peuples, exécutés en modèles, sous la direction de L.F. Cassas (Paris, 1806), p. xi: “[...] les modèles en relief, suscetibles d'être éclairés à tous les effets du jour, ou de recevoir la nuit au moyen de lumières adroitement ménagées, un clairobscur pittoresque et souvent magique, dont les peintres d'histoire et de décorations peuvent tirer le part le plus avantageux, pour mettre dans leurs tableaux le style convenable au sujet qu'ils traitent et la vérité la plus parfaite". 


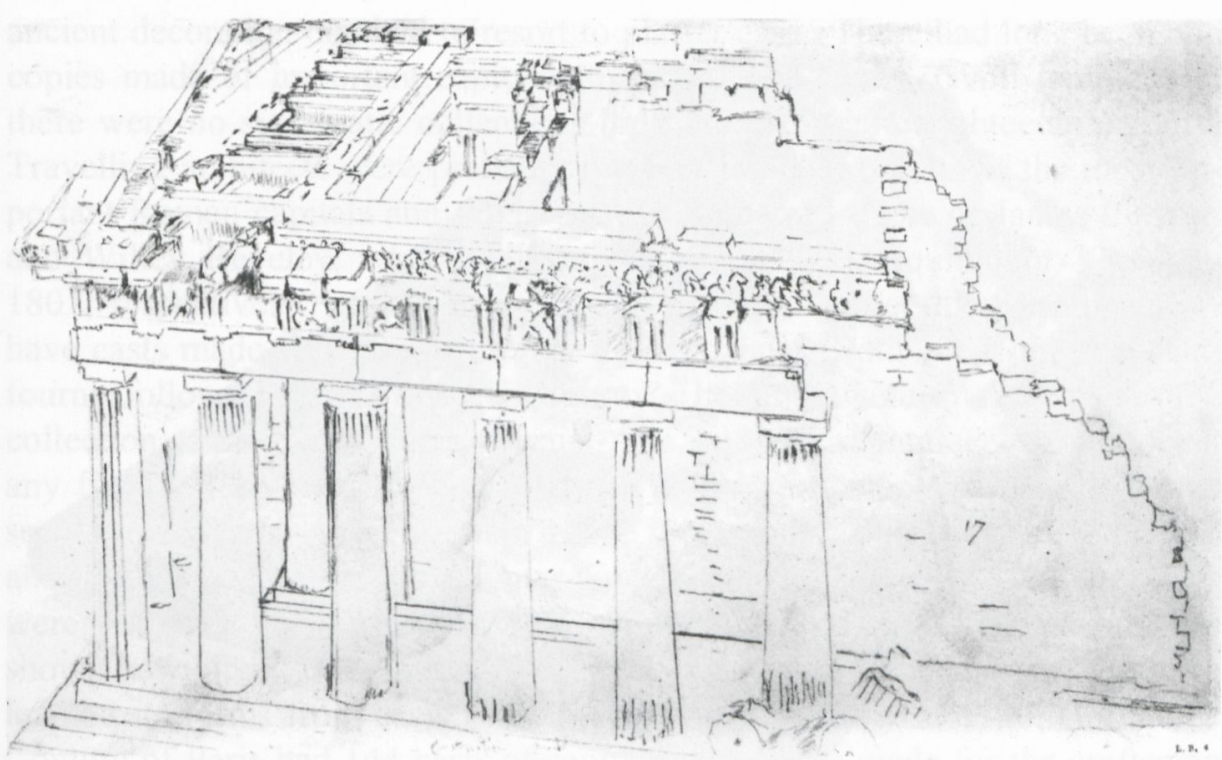

Fig. 23. 5: Study of L. S. Fauvel's plaster model of the Parthenon, by William Gell 1812. Graphite and wash on paper. British Museum, London.

decades, Fauvel's house was the most important point of reference for the few travellers who visited Athens before the end of the wars of liberation against the Turks. Luigi Beschi has succeeded in reconstructing his collections rather exactly. ${ }^{19}$ Besides a number of original sculptures - which paled against the results of Lord Elgin's raids - Fauvel owned several plaster casts, for example of the metopes of the Parthenon or the Hephaisteion and plaster models of several ancient buildings on the Acropolis. ${ }^{20}$

The plaster model of the Parthenon, of which a drawing by William Gell has remained (Fig. 23. 5), must have measured about a meter in length and showed the temple as a ruin. ${ }^{21} \mathrm{We}$ can only speculate why Fauvel was the only modellist

19 Beschi, 'La casa di L.S. Fauvel'.

20 Fauvel produced a first series of models in the years 1788-1797, that have since been destroyed. New models had been wrapped up in cases in 1823 but never reached Smyrna, where Fauvel lived. P.-E. Legrand, 'Biographie de Louis François Sébastien Fauvel, antiquaire et consul (1753-1838)', Revue archéologique, 31 (1897), II, pp. 100, 188; Beschi, 'La casa di L.S. Fauvel', pp. $102-8$, list of models, pp. 110-11.

21 Scale: 2 lignes par pied $=1: 72$. The bigger models of Fouquet are 4 lignes par pied $=1: 36$, M. Wienke, 'Fauvel's model of the Parthenon and some drawings of Gell from the time of Elgin's Mission 1801-1803', American Journal of Archaeology, 78 (1974), pp. 184-5, at p. 184. For a good illustration see F. Brommer, The Sculptures of the Parthenon (London, 1979), p. 34, fig. 17. 


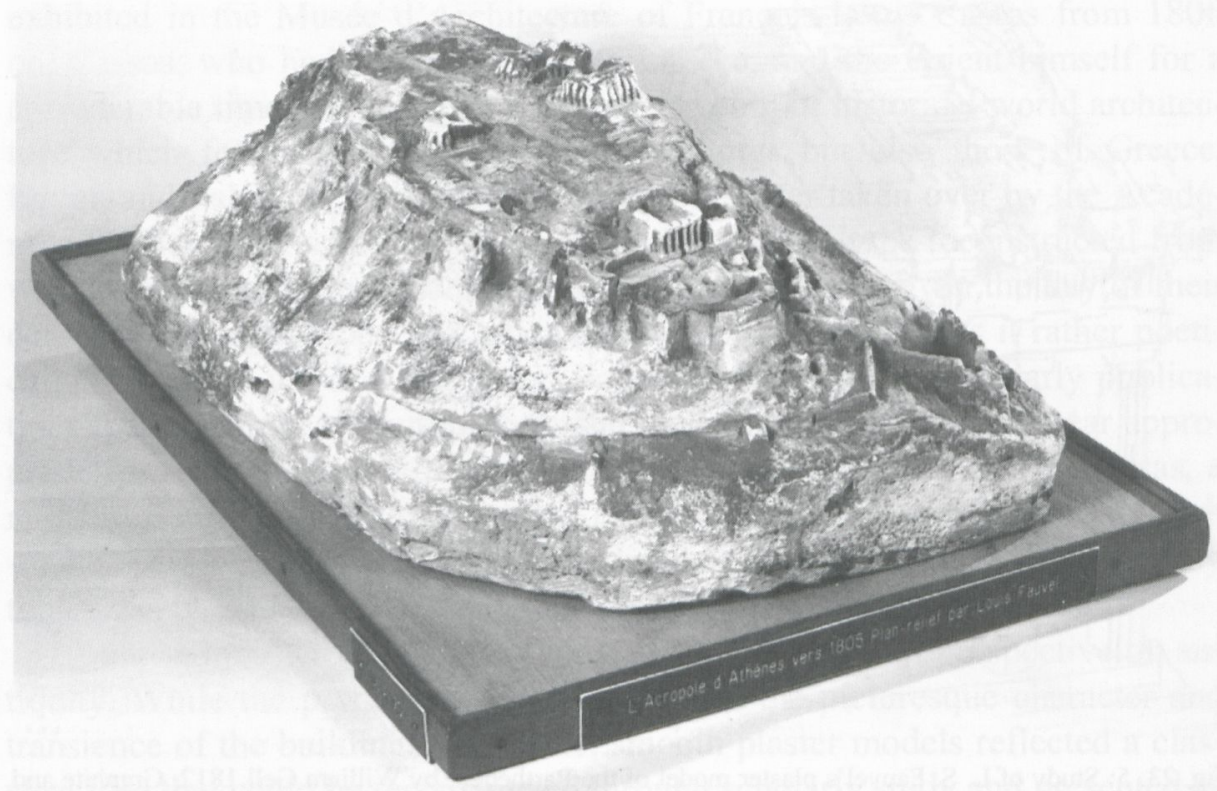

Fig. 23. 6: Model of the Acropolis of Athens. L. S. Fauvel, c. 1805. Plaster, h: $43 \mathrm{~cm}$, w: $27 \mathrm{~cm}, 1: 14$ $\mathrm{cm}$. Bibliothèque Nationale, Dept. Cartes et Plans, Paris.

to depart from the rule of reproducing ruins with cork, even though he is very likely to have known this technique from his mentor, Choiseul-Gouffier. We may assume that plaster was regarded as better suited to the reproduction of Greek marble. Finally, Fauvel constructed three other plaster models showing three-dimensionally the Acropolis (Fig. 23. 6), Athens and the whole of Attica, respectively. ${ }^{22}$ It was not unusual at the time to make relief maps from wax or plaster, but these cartographic works, which are stored in the Bibliothèque Nationale, remain unique in early nineteenth-century archaeology.

\section{Plaster Casts of Architectural Elements}

Models were generally to be found in collections used for training young architects. The underlying idea was to reproduce ancient architecture as a whole, to show the relation of the single components to one another and their overall proportions. However, in order to study and copy individual forms of

22 Beschi, 'La casa di L.S. Fauvel', p. 110 and figs 19 - 21. In 1812 Fauvel worked on a model 12 feet long. This cannot be identical with the one $(43 \times 27 \mathrm{~cm})$ in Paris. 
ancient decoration one had to resort to plaster casts. There had long been odd copies made of important capitals, such as those of the Tivoli temple. But there were no systematic collections until the end of the eighteenth century. Travelling architects were probably the first to acquire casts of the most important Roman capitals and ornaments. In England I know of James Playfair and Willey Reveley, whose collections John Soane acquired in 1795 and 1801, respectively. ${ }^{23}$ In France, Nicolas-François-Daniel Lhuillier began to have casts made in Rome in the late $1770 \mathrm{~s} ;{ }^{24}$ later, from 1782 on, Leon Dufourny followed. ${ }^{25}$ Ultimately, Dufourny's holdings were integrated into the collection of the Académie des Beaux-Arts, but we cannot trace them in detail any further. Choiseul-Gouffier also had casts of architecture made from his second journey to Asia Minor in 1786; incidentally, they were made by the above mentioned Fauvel, the later French consul in Athens. ${ }^{26}$ These casts were not produced for academic purposes alone. Margaret Richardson has shown how often Soane used the Tivoli capital, and his stonemasons will have learned its forms from casts. ${ }^{27}$ During a journey to Italy in 1790 , Guillaume Couture of Paris had 144 casts of capitals and details made for the craftsmen working on the Madeleine, so that they would have a clearer idea of what the final details should be. ${ }^{28}$ There were two types of casts. Both can be seen in Soane's Museum in an exemplary form. One form focused on single leaves, volutes, or kymatia. They were easier and less expensive to manufacture, but they could only be used as models for these details. The other type represented the capital as a whole, or even sections of entire arrangements with base, capital, and entablature. Capitals in particular had to be composed of many individual parts. But arrangements of this sort provided a wholly different, intrinsically scientific, approach to the proportions of ancient architecture, rendering these proportions palpable to the observer.

However, there were no systematic collections until the early nineteenth century. Through the work of Pinatel, we know of the efforts of the Académie des Beaux-Arts to replace old damaged casts - for example Dufourny's 'Galérie

23 Dorey, 'Soane as a collector', in Thornton and Dorey (eds), A Miscellany of Objects, p. 124.

24 Szambien, Le musée d'architecture, pp. 23, 44-5.

25 Szambien, Le musée d'architecture, pp. 22-7 and passim; Pinatel, 'La restauration en plâtre de deux colonnes', pp. 78-80.

26 Szambien, Le musée d'architecture, pp. 24, 60. Fauvel produced casts of the 'Lantern of Demosthenes' (monument of Lysikrates) before 1802. They included probably the capital and other architectonic elements, Szambien, Le musée d'architecture, pp. 50-1.

27 M. Richardson, 'John Soane and the Temple of Vesta at Tivoli', Architectural History, 46 (2003), pp. 127-46.

28 Szambien, Le musée d'architecture, pp. 25 -7 with fig. Among these casts was a capital of the temple of 'Mars vengeur' $2.41 \mathrm{~m}$ high. 


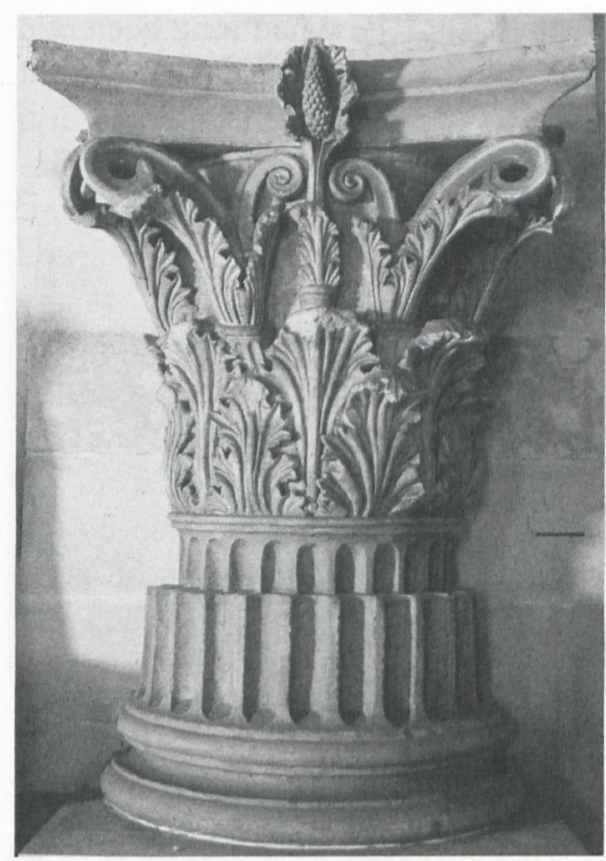

Fig. 23. 7: Cast of the order of the so-called temple of Hercules in Rome (the circular temple at the Forum Boarium). Académie des BeauxArts, Paris, 1829. Plaster. Petits Écuries, Versailles.

d'Architecture' - and to obtain a representative selection of the most important ancient architectural orders (Fig. 23. 7). ${ }^{29}$ The correspondence between Paris and the different directors of the Académie de France in Rome, located in the Villa Medici, reveal several aspects of these efforts. Sometimes they tried to use an English architect's scaffold (we do not know if it was that of John Sanders or of Lewis Wyatt) in Rome in order to keep expenditure down, sometimes the casts turned out to be of inferior quality, and sometimes an entire package was destroyed through mishandling during shipping. The artisans who were employed, such as the Malpieri and Giacomini families, worked for both the French and the English. $^{30}$

Two letters that Soane's eldest son, John, sent to his father, shed light on the English activities. John Jr. was in Rome in late $1819 .{ }^{31}$ In his letters,

he describes the activities of several English architects such as John Sanders - a student of Soane's - and his collaborators, Taylor and Cresy: "They measure every thing $[\ldots]$ Coloured drawings, casts, with all the etceteras - yes and a model of the different levels in the Forum." He continues: "If I am not misinformed, you have a cast of the Tivoli capital [...] I have an opportunity of purchasing one very reasonably, but it is not worth while, to have two." However, two weeks later he has already changed his opinion: "The practice of

29 Pinatel, 'Les envois de moulages d'antiques', in Lavagne and Queyrel (eds), Les moulages de sculptures antiques.

30 Pinatel, 'Les envois de moulages d'antiques', in Lavagne and Queyrel (eds), Les moulages de sculptures antiques, pp. 81-2, with notes 49, 55, 80, 90, 92 on pp. 100-4 (Leopoldo, Benedetto and Vincenzo Malpiero; Filippo Giacomini). A certain Benedetto (Malpieri?) worked for Lewis Wyatt in 1820, who sold these casts of sculpture and architecture to Soane in 1834. Dorey, 'Soane as a collector', in Thornton and Dorey (eds), A Miscellany of Objects, p. 124.

31 A. T. Bolton, The Portrait of Sir John Soane... Set Forth in Letters From his Friends (London, 1927), pp. 281-3. 
casting from clay moulds is abominable, and makes me less anxious to purchase casts, altho' I can get them for England free. I propose having single leaves only of the different capitals, unless you wish for those." While plaster casts could serve as integral parts of an extensive documentation project, then, one had to be careful to distinguish good from bad copies and to pay an appropriate price. In the unhappy son's view, even single leaves might suffice to represent details.

These series of casts are not archaeological documents in the original sense. Rather, they made it

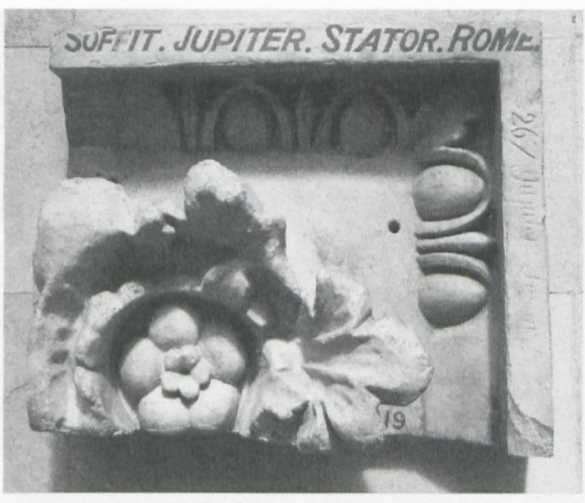

Fig. 23. 8: Cast after a coffer from the soffit of the entablature of the temple of Jupiter Stator (Dioscuri) in Rome. Académie des Beaux-Arts, Paris, nineteenth century. Plaster, h: $18 \mathrm{~cm}$, w: $30.6 \mathrm{~cm}, 1: 37 \mathrm{~cm}$. Museum für Abgüsse, Munich. possible to study ancient architecture directly, at a distance from the monuments themselves: to study in an affirmative sense, that is, with the aim of learning to insert these elements 'correctly' in one's own design. The arrangement of the casts in the Académie follows this line of thought. Apart from the column's shaft, that is missing, the elements of temple architecture are neatly piled up. There is no fundamental difference between this concept and the standards of architectural drawing evident, for example, in a contemporary drawing of von Gärtner, the Munich architect.

But the Académie did not only purchase casts; they sold copies of them as well. ${ }^{32}$ These were produced in a moulding studio that belonged to the Académie. These pieces, most of which are rather small, follow the principle of exemplary detail (Fig. 23. 8). The serial character of ancient ornamentation is used with precision: a band of ornaments can be represented with only two elements and, if necessary, a corner node; the profile of a coffer or a Corinthian capital can be shown by no more than a quarter; for a Doric capital, one needs no more than a small segment. These are three-dimensional samples of a reper-

32 Pinatel, 'La restauration en plâtre de deux colonnes', p. 91 note 111, p. 106 note 150 , fig. 26 (sales catalogues of Desachy 1881 and Sadaune, from the end of the 19th century). The Museum für Abgüsse Klassischer Bildwerke in Munich keeps such copies, bearing an inscription in an oval field: 'Académie Royale des Beaux-Arts'. I do not know, if they can be dated to the years between 1820 and 1848, or if the moulds remained unchanged after the end of the French monarchy. The Munich casts are on loan from Cambridge University. I am indepted to I. Kader for having provided this useful information. 


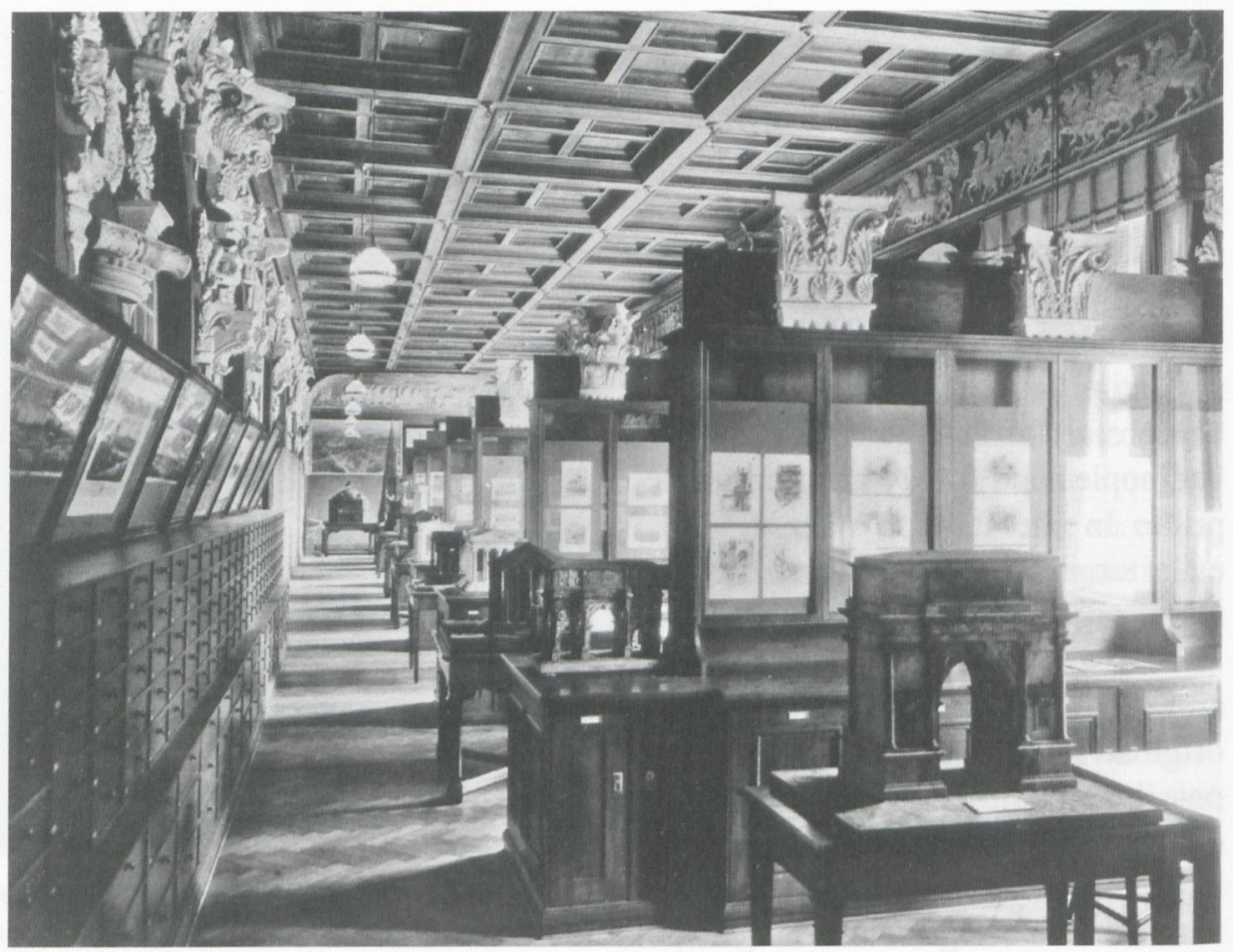

Fig. 23. 9: Architectural collection of the Technische Hochschule, Munich, 1917.

toire of ancient ornament, selected for studying and copying. Details of this kind made their way into collections of art and architecture, where students were surrounded by them and had to draw them again and again. In this respect, there are remarkable similarities between John Soane's drawing studio (Fig. 35. 10) in the early nineteenth century and the Architectural Museum of the Munich Technische Hochschule that dates from the First World War (Fig. 23. 9). ${ }^{33}$

Full-size reproductions were the final step on the way to convincing evocations of ancient architecture. While there had long been reproductions of the most popular ancient ruins or temples, these were usually much smaller than the original. The copies exhibited in the 'Colosseum' garden of Regents Park around 1830 , for instance, were sized down considerably. As late as 1854 , in the Greek Court of the Sydenham Crystal Palace, the architects had to confine

33 W. Helmberger and V. Kockel, 'Herkunft und Geschichte der Aschaffenburger Korkmodellsammlung, in W. Helmberger and V. Kockel (eds), Rom über die Alpen tragen (Landshut 1993), pp. 119-26. 
themselves to showing the columns of Nemea half their original size. Their reconstruction of the façade of the Parthenon amounts to no more than $2 / 9$ of the original. ${ }^{34}$ The big steel and glass constructions used for the courts of the Académie des Beaux-Arts (1876) and the Victoria and Albert Museum were the first to accommodate replicas of entire corners of temples. Moreover, new techniques had to be developed to guarantee the stability of these big reconstructions. For Paris, Christiane Pinatel has described the elaborate methods to which the architects Ferdinand Dutert and Ernest Coquart resorted when they reconstructed two columns and the entablature of the Roman temple of the Dioscuri (Fig. 23. 10) as well as a corner of the

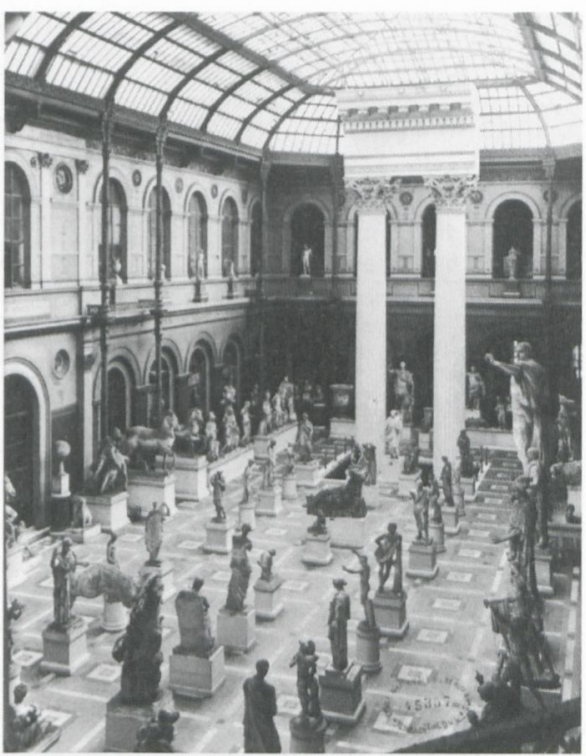

Fig. 23. 10: Reconstruction of two columns of the temple of Iupiter Stator (Dioscuri) in Rome. Plaster, h: $18.6 \mathrm{~m}$. Once Académie des BeauxArts, Court Vitré, Paris. Parthenon. ${ }^{35}$ It was now finally possible for the Parisian to experience physically the true proportions of ancient temple architecture. In some respects, the replica was even more convenient than the original: while in Rome one had to use binoculars to look at the ornaments of capitals and entablatures, in Paris these could be studied conveniently in additional copies.

But these gigantic reconstructions remained the exception (Fig. 23. 11). ${ }^{36}$ By the time they were built, the value of copies - as opposed to originals had already begun to decline. Nevertheless, individual samples of ancient ornament formed a part of collections of archeological institutions and architectural academies for a long time. As late as 1916, an architectural collection was established in Munich whose conception - drawings, models, and casts of

34 G. Scharf, The Greek Court Erected in the Crystal Palace (London, 1854), pp. i-ii, p. 6.

35 Pinatel, 'La restauration en plâtre de deux colonnes'. Both 'temples' have been reerected in the Petite Écurie in Versailles.

36 The Paris temples have been repeated in Moscow. In 1886 the façade of the temple of Zeus in Olympia was reconstructed on a 1:1 scale during an exhibition in Olympia (in stone, covered with plaster). E. Fabricius and L. Pietsch, Führer durch das Pergamon- und Olympia-Panorama (Berlin, 1886), pp. 8-9 for the archaeological impact. 


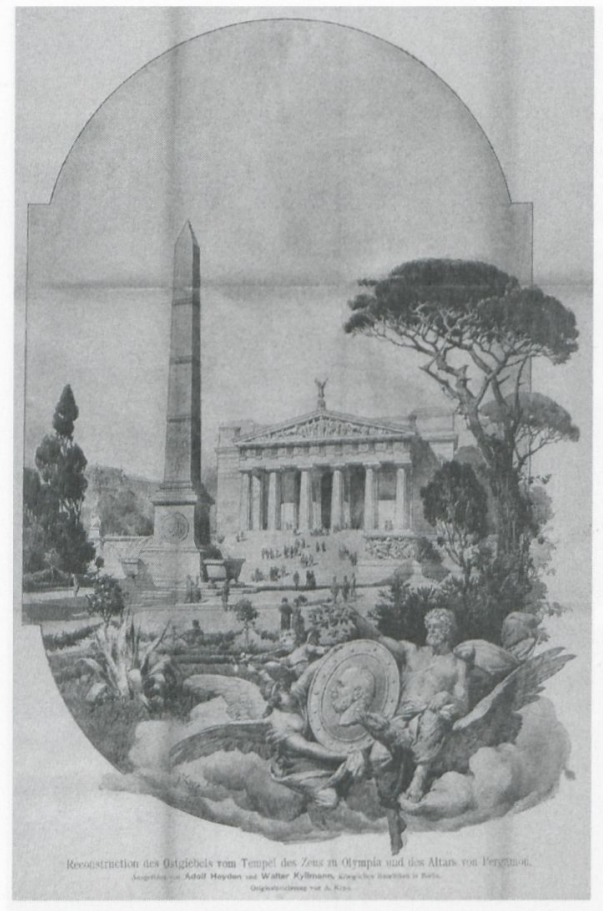

Fig. 23. 11: Reconstruction of the eastern front of the temple of Zeus in Olympia. Exhibition of the Academy of Fine Arts, Berlin 1886 (now destroyed). From: E. Fabricius and L. Pietsch, Führer durch das Pergamon- und OlympiaPanorama (Berlin, 1886), frontispiece.

ancient and medieval buildings - was hardly different from its precursors of the early nineteenth century (Fig. 23. 9).$^{37}$ Like many other German collections, this one was largely destroyed during the Second World War; others were neglected, stored away or scattered. A number of the articles in this volume testify to this development. It is only rather recently that the different 'genres' of three-dimensional reproductions of architecture - model, cast, reconstruction - have regained some of the esteem they formerly enjoyed. But today they can hardly be understood as invitations to aemulatio. Rather, they bear witness to a past epoch in which antiquity and its study had an importance far different from today.

37 J. Popp, in M. Schröter and W. Lynen (eds), Die K. B. Technische Hochschule zu München: Denkschrift zur Feier ihres 50jährigen Bestehens (Munich, 1917), pp. 128-9. 


\section{Frequently cited literature}

L. Beschi, 'La casa di L.S. Fauvel, primo museo ateniese', Archaiologike Ephemeris, 140 (2001), pp. 72-120

H. Dorey, 'Soane as a collector', in P. Thornton and H. Dorey (eds), A Miscellany of Objects From Sir John Soane's Museum (London, 1992), pp. $122-6$

P. Thornton and H. Dorey (eds), A Miscellany of Objects from Sir John Soane's Museum (London, 1992)

C. Pinatel, 'Les envois de moulages d'antiques à l'École des Beaux-Arts de Paris par l'Academie de France à Rome', in H. Lavagne and F. Queyrel (eds), Les moulages de sculptures antiques et l'histoire de l'archéologie (Geneva, 2000), pp. 75-120

C. Pinatel, 'La restauration en plâtre de deux colonnes du temple de Castor et Pollux dans la Petite écurie royale de Versailles. Histoire et archéologie', Revue archéologique, (2003), pp. 67-114.

W. Szambien, Le musée d'architecture (Paris, 1988) 